\title{
PEKERTI TRAINING TO IMPROVE LECTURERS' INSTRUCTIONAL QUALITY AS PROFESSIONAL ACADEMICS
}

Dr.Agus Prasetya, MSi.dan Drs.Stefani, MPd

aguspratya@ecampus.ut.ac.id/snawati@ecampus.ut.ac.id

\begin{abstract}
Social phenomena in the higher education environment currently sees competition for academic staffs to obtain functional positions in order to obtain social status and recognition as lecturers. Academic staffs are required to have the following competencies namely pedagogical, academic, social, personal, professional and to improve their competencies by participating in trainings such as Aplied Approach (AA) training. By participating in AA training, an academic staff is required to understand what must be possessed as a lecturer especially in making Lecture Even Unit or Tutorial Program Design and Tutorial Event Unit. The objective is to carry out technical training so that the lecturer understands instructional basic techniques such as teaching methodologies, understanding teaching and learning techniques, teaching evaluation, understanding and being able to make the Tutorial Program Design and Tutorial plan, so that they become professional academic personnel. namely affective social actions, specific social actions, social actions on the basis of values and traditional social actions. The expected final results with AA-type training, the ability of lecturers to manage teaching learning process is more quality so that professional academics are created, besides being one of the certification requirements.
\end{abstract}

Keywords: Pekerti, Applied Approach, academic staff, lesson plan, Tutorial Program Design, Tutorial plan, social act.

\section{Introduction}

Several professions that received respectable social status in the community are educators, teachers, and lecturers. Educators (teachers, lecturers, ustadz) are positions that are dignified by society, especially along with the improving condition in which teachers gain more security in terms of socially and financially. With the issuance of Law No. 14/2005 concerning teachers and lecturers providing formal legal strength in a legal profession, lecturers in the community. The purpose of Higher Education, is, (1) the development of student potential. (2) produced graduates who master the branches of Science and Technology. (3) the production of Science and Technology, and (4) the realization of reasoning based research and research works (UU. No 20 / year 20015). In the future 
teachers, lecturers who have the quality of professional human resources are needed. In the past the teaching profession was shunned by the public, especially young people, allergies became educators (teachers) because socially economically was not good, the income of teachers was minimal, just enough to meet daily needs. Along with the Law. No. 14 of 2005, slowly but surely the government pays attention to socio-economic conditions, the welfare of teachers improves with the existence of professional profession allowances for teachers. Certification of teachers and lecturers is fast, slow to improve the welfare of teachers and lecturers. For this reason teachers and lecturers must improve the qualifications of human resources through further study of S1, S2 and S3, lecturers should equip themselves with the necessary infrastructure facilities. A lecturer needs educational media such as laptops, LCDs, English courses, IT courses, so that lecturers are created and professional teachers.

According to PP. No.19/2005 Article 91 concerning national education standards, every formal and non-formal education must carry out quality assurance. Therefore, according to UU.No. 14/2015 article 1 point 2, lecturers should be able to carry out their duties as educational media and professional scientists (2014: 1) In order to improve the ability of lecturers, Kopertis organizes skills training in interactional basics as a means to equip conventional / face-to-face lecturers in making the Lecture Event Unit (LESSON PLAN). A lecturer must have more knowledge, and more knowledge, then in Law No. 14 of 2005 it is stated that the teacher must be at least a S1, while a lecturer in a university must be at least a master's degree, a S2 lecturer must have a S3 education level, a S3 lecturer must at a minimum a great teacher (Professor). Thus by implementing regulations, about when, where, what capacity is an educator is clearly the professionalism of an educator must be owned by a lecturer (2005: 8). Problems on our campus, both public and private, at the scientific level of lecturers, state that not all lecturers already understand Pekerti. Training, understanding instructional problems in the teaching and learning process, didactic, methodical, evaluators are not owned by a lecturer, especially young lecturers. There are not many young lecturers in carrying out their duties and functions as educators, so there are still many shortcomings in the teaching and learning process here and there. The spirit of encouragement as an educator is still burning, let alone just graduating S2, so that in teaching there is less preparation of tools, facilities, infrastructure, lecturer tools. Lecturers should be required to have, understood, mastered, namely the Basics of Instructional skills as lecturers in universities.

According to the Higher Education law No.12 of 20012, the function of higher education (2014: 9) is (1) developing, science and technology by paying attention, applying the values of the humanities. (2) an innovative, responsive, creative, skilled, competent, cooperative 
academic community through the Tri Dharma of Universities. (3) as well as the ability to form a dignified national character and national civilization in the intellectual life of the nation. Lecturers in carrying out their duties and obligations if only armed with what they are without good preparation in making the lecture unit, the lecturer behavior results in the teaching and learning process is not clear what competencies are achieved at the end of learning. this is what is called "suicide in the profession". Lecturers must abandon this behavior in the teaching and learning process, because if not, it will cause reactions from students, the community. The problem that arises is the provision of courses that do not reach the target. This is the beginning of the destruction of the lecturer in carrying out his profession.

According to the 2015-2025 KPPTJP Dikti, for a lecturer to function professionally, the lecturer must have 3 compulsory competencies that are understood, namely pedagogic competence, social competence, personality competence and professional competence (2005: 21). Before starting to give face-to-face lectures in class, the lecturer must prepare the Lecture Event Unit and must be brought during the meeting. There is no one, lecturer teaching without carrying tools, teaching tools in carrying out the tasks. It was intended that the learning outcomes at the end of the semester be clear in accordance with the syllabus, the existing curriculum. This is where the importance of a lecturer has a Pekerti certificate and applied approach to gain knowledge about the instructional basics of higher education. Through training in Instructional basics in higher education, a reliable professional academic / lecturer is created in carrying out his duties as a lecturer (Pekerti 2014: 6)

In order to improve the quality of the learning process in higher education, it is necessary to creatively develop new, more comprehensive and competitive educational concepts. Understanding of the basics of higher education instructional institutions that have not been mastered and understood by lecturers in carrying out their duties and functions. Many lecturers do not prepare the material well according to the rules of Instructional basics in the form of LESSON PLAN. If there is a lecturer who does not carry teaching equipment and tools in the form of LESSON PLAN, it should not be allowed to enter classes or boarding rooms. Laziness, forgetfulness of lecturers to make, LESSON PLAN still haunts a lecturer in making teaching preparations, lecture preparation and this is what should be resisted, avoided by lecturers. These things make the final achievement expected by a student fail to be fulfilled in the learning process of learning. Other reasons are often used as "shields" by lecturers because there is no time and keep busy with their activities, and the material has memorized the head so that it does not need to make LESSON PLAN, in giving lectures. 
The Instructional Basics Skills Training in higher education (PEKERTI) aims to enable lecturers to be able to understand the basics of Instructional higher education. An academic / lecturer must be able to make and carry out lecture units (LESSON PLAN) when giving lectures, according to procedures determined by the Law No. 19 of 2005, concerning National Education standards. (2014: 21). With Pekerti training young lecturers are expected to be skilled, able to compile, create, design, practice microteaching well. So that later they become professional lecturers in carrying out their duties and obligations in accordance with curriculum guidelines that have been set for each education unit.

At present there are still many lecturers in giving lectures that do not carry out, make lesson plans, design program tutorials and program tutorials. Though the learning tool is a "life" that provides a purpose, direction, which contains the design of learning for 1 semester that contains the indicators and final abilities expected of students after learning ends. Lecturers are professional educators and scientists are tasked with transforming, developing, disseminating, technology science and art through education. Lecturers as professional staff function to increase dignity and role as agents of learning (UU. No. 14/2005). If a lecturer, teacher does not bring, make, arrange lesson plans, Design Tutorials and Unit Events Tutorials, the teaching and learning process can be predicted in lectures, tutorials "carelessly" have no clear direction, purpose.

\section{Literature Review}

In this article, the author uses Max's Social Action theory. Weber, a Sociologist from Germany who is famous for his Social Action theory, to explore the purpose, why Pekerti training is held. Social action is a process, in which actors are involved in subjective decision-making about means and ways to achieve certain goals selected. This action is meaningful human behavior oriented to the behavior of others in their duties as lecturers in teaching and learning in the classroom ..

Max Weber, (Ritzer, 2011: 110) his attention to action theories is oriented to the goals and motivations of actors, does not mean that Weber is only interested in small groups, in terms of specific interactions between individuals. Max Weber also pays attention to the great trajectory of history and social change, and believes that the best way to understand various societies is to appreciate the typical forms of action that characterize them. Max Weber carried out reconstruction of meaning, behind historical events that produced social structures and formations, but at the same time looked at all configurations of unique historical conditions. 
Max Weber (Pip Jones, 2009: 114) mentions the methods used in appreciating the social environment in which they are verstehen. Because in Sociology, Sociologists also humans must understand their actions according to their goals. Menururt Max Weber type of social action according to the type of action, classified into 4 (four) in harmony with his motivation:

1. Traditional action, which is a human action that has become a habit every day they do, so that it becomes an ordinary thing. Example: "I do this because I always do".

2. Affective actions, namely actions based on beauty and certain motivations.

3. Actions that are oriented to value or use value rationality, namely the actions of a person based on a rational value according to the perpetrator.

4. The action is goal oriented or uses instrumental rationality. Namely action by someone who is the most efficient to achieve the goal and the best way to achieve it.

Max Weber (Pip Jones: 2009; 113) that humans can compare the structure of society by understanding the reasons why these people act, historical events that affect their character, and understanding character and understanding current behavior, will not be able to generalize the whole community or all social structures. A sociologist should use the widest range possible.

According to Max Weber, social action is an action that has subjective meanings for and from the perpetrators (Johnson, 1986). Actions of social action to achieve expectations in the activities of training in Instructional Higher Education (Pekerti). These actions are based on the awareness of beliefs about values such as ethics, aesthetics, religion and other values that can influence human behavior in their lives. Social actions are determined by the psychological condition and feelings of the actors who do it, and actions based on habits that have ingrained (Jonhson, 1986).

\section{Research Method}

This research used qualitative research, where the method of data collection is in the form of answers in the form of narratives, stories, expressions of words given by the object of research. While the data sources are some of the Pekerti committee and training participants and resource persons. Retrieval of data using observation methods, independent interview, documentation. Data Analysis uses "Interactive" models Miles and Hubermann with the following steps, among others: Data collection, Data Reduction, Data Display and Verivying / conclusion. by Miles and Huberman. (Huberman: 2017: 200) 


\section{Results and Discussion.}

a. Discussion

This research is based on the assumption that the need for academically qualified lecturers is relevant to the position, the academic improvement of lecturers is needed so that professional lecturers can be reached, so the lecturers' education qualifications are postgraduate. Quality and professional HR lecturers are very important. with regard to these problems, a theory is needed, such as for example: the theory of social action from W.Weber to examine the behavior of lecturers.

The social definition paradigm, see that the quality of a person is determined by external factors that are compelling and controlling individuals. The social definition paradigm, emphasizes actions based on subjective meanings. Lecturer behavior in fulfilling his duties and responsibilities as a lecturer to obey and carry out on didactic procedures, methodically aligned with the basic Instructional skills of higher education which has become the provisions of the Higher Education, Action someone will repeat when getting the expected reward, whereas if there is no reward from institutions cause "death of spirit". Below is discussed the steps of lecturer social action in training Instructional skills in higher education (Pekerti) through schematic thinking framework of lecturers' social actions in improving personality abilities, pedagogic abilities, social abilities and professional abilities. There are 4 (four) one's own social actions through training in Instructional basics. Namely 1) Social action oriented to a particular goal, 2) Social actions that have affective values, 3) Certain social actions, and traditional social actions. Participating in Pekerti training is an affective social action, action is full of values and has a specific purpose. 


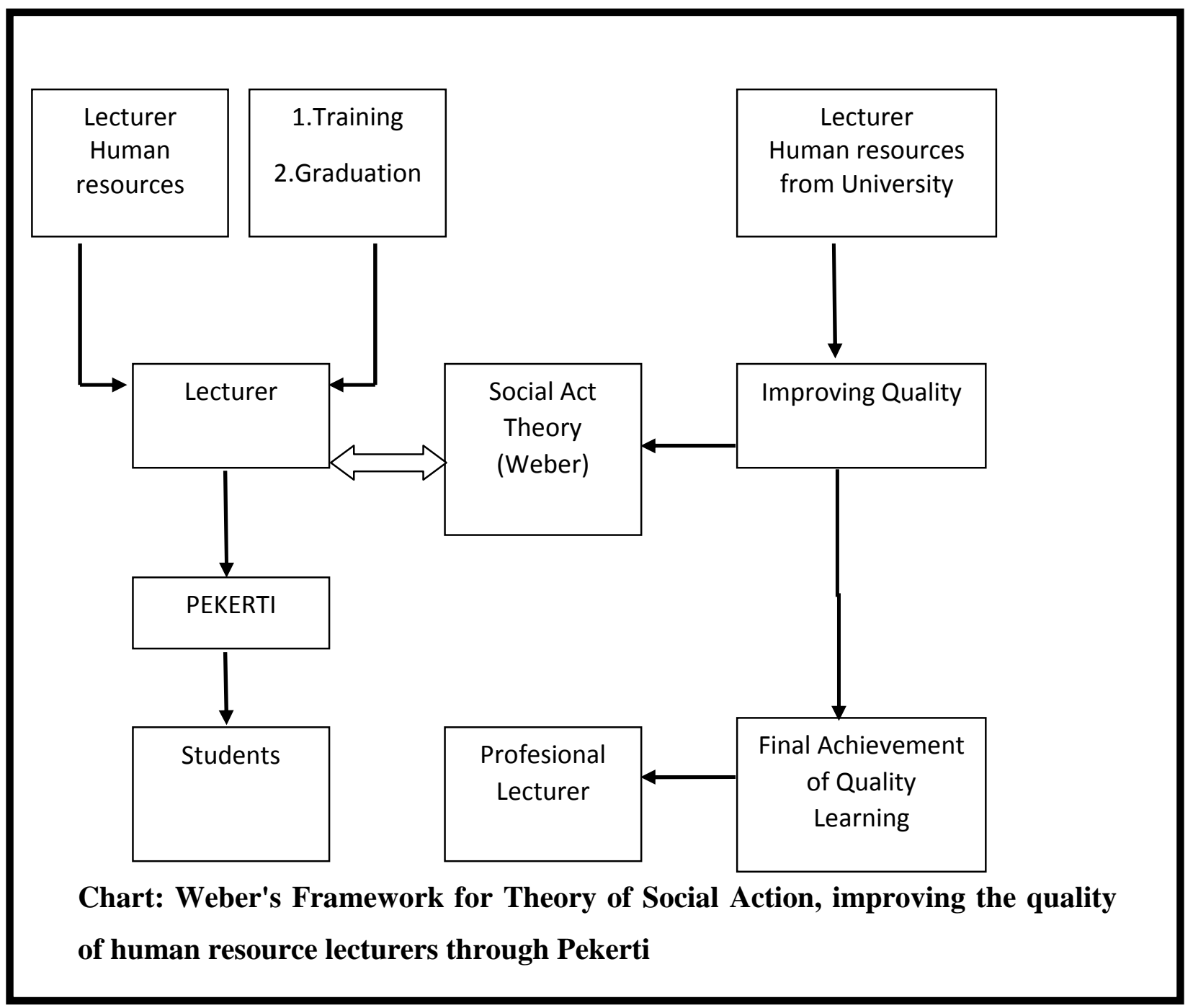

From the above theoretical framework, it can be explained that to improve the quality of lecturers, lecturers need social actions, this is needed to create qualified lecturers. To improve the quality of human resources, lecturers need professional lecturers to carry out lecturers' duties and procedures well. The lecturer must make, implement SAP, which has been given in Pakerty Traing, because it can improve the quality of lecturers in the teaching and learning process in higher education.

\section{b. Results and Findings}

Social action carried out by someone has various motivations in improving the quality of the human resources of the lecturer. Lecturers' behavior has not been able to improve the quality of professional lecturer human resources, which can improve the performance of lecturers in carrying out their duties and obligations. Therefore the participation of young 
lecturers in Pekerti training conducted by Kopertis is an affective social action and social action that is full of values and specific objectives for the lecturer.

Pekerti training by lecturers is not a traditional action by a person, namely an act that has been in effect for days, but is a social action that has an affective value and an action that is full of values and aims that are noble and good. The findings in the Pekerti training which were observed and through the process of observation, Indepth Interview during Instructional basics training, took place at Uniska Kediri from the 13th to the 18th of January 2019.

\section{Conclusion}

A good lecturer is an educator who has a sense of responsibility in educating students sincerely, seriously, seriously, responsibly, because the teaching profession is very noble and has a high social status in the community. This study would like to offer some suggestions as follows:

1. Remembering a noble profession, then a lecturer is required to take responsibility seriously, in carrying out his work. It is a necessity for a lecturer to master, understand, understand, instructional basics in giving lectures and tutorials to students.

2. By attending the Higher Education Instructional Basics training, it is expected that the lecturers in carrying out their duties and responsibilities understand the problems in giving lectures to students.

There is no ivory that is not cracked, as smart as a squirrel jumping must have fallen one day too, as great as a lecturer in carrying out his duties as a knowledge carrier, sometimes forgetting, neglecting, already making lesson plans or not. A lecturer needs to continually learn about Instructional basics in carrying out professional assignments. In order for a lecturer to be respected, respected, respected by the community and students, the lecturer must prepare himself very well before giving lectures. Lecturers should prepare themselves by making lesson plans well, before giving lectures.

\section{References}

Anonim (2006) Pendidikan Untuk Pendidikan Berkelanjutan Petunjuk Guru.Jakarta.

Bogdan, Robert R and Steven J.Taylor.(1993) Dasar-dasar Penelitian Kualitatif. Surabaya Aneka Usaha.

Collemen James.2008 : Dasar-Dasar Teori Ilmu Sosial .Bandung Nasional. 
Creswel. John .1988. : Qualitatif and Research Page: Choosing Among Five.Tradition :TradiditionStates of America Sage Publishing Inc.

Depdikbud. 1995. Kamus Besar Bahasa Indonesia Edisi ke 1 Balai Pusataka.

Djam'an Satori, 2012. Profesi Keguruan, Karunika Univversitas Terbuka Jakarta.

Gidden Anthony and Jonathan Turner: : Socially Theory Today, Jogjakarta, Pustaka Pelajar.

Furchan Arief. 1992. Pengantar Metode Kualitatif Surabaya Usaha Nasional.

Fisher, and Strauss A : Thir Succes, Symbolice Chicago Tradition : Thom.IPark and the inc.

Kementrian Pendidikan Dan Kebudayaan . 2016. Katalog Universitas Terbuka. Tangerang: Penerbit Universitas Terbuka.

Tim Fasilator Pekerti.A.Kopertis,2014. Pelatihan Pengembangan Ketrampilan Dasar Instruksional (Pekerti), Koordinasi Perguruan Tinggi swasata wilayah VII

Miles, Mattthew B, and Hubermann,A.Michael, 1992.Analisis Data Kualitatif, Buku Sumber Tentang metode-metode Baru. Jakarta: UI Press.

Moleong LexyJ,2007,Metode Penelitian Kualitatif. Bandung: Remaja Rosda Offset.

Ritzer George, Goodman D. 2007.Teori Sosiologi Modern.Edisi terjemahaan Alimandan, Jakarta: Kencana.

Ritzer, George, 2009.Teori Sosiologi, Yogjakarta: Kreasi Kencana.

Pip Jones. 2012. Teori- Teori Sosial. Penerbit : Obor Indonesia.Yogjakarta. 2012.UU.No.14/ Tahun 2005. Undang-undang tentang Guru dan Dosen.Genesis Learning.Bantul, Yogjakarta.

UU.No 12/ Tahun 2012, tentang Pendidikan Tinggi, Bina Ilmu Surabaya. 2012. 